\section{Vietnam Journal of Agricultural Sciences}

\title{
Students' Perceptions of Climate Change: A Case Study at Vietnam National University of Agriculture
}

\author{
Nguyen Thi Bich Yen, Dinh Thi Hai Van, Nguyen Thi Thu Thuy \\ \& Duong Van Hung
}

Faculty of Natural Resources and Environment, Vietnam National University of Agriculture, Hanoi 131000, Vietnam

\begin{abstract}
This study aimed to determine the perceptions of climate change of undergraduate students at Vietnam National University of Agriculture (VNUA). The study employed quantitative and descriptive methods using a five-point Likert scale instrument. The respondents were composed of 276 undergraduate students from three faculties, viz. the Faculty of Environmental Sciences (FES), the Faculty of Agronomy (FA), and the Faculty of Economics and Rural Development (FERD). The results showed that students were generally well aware of the causes of climate change, the effects of climate change, and actions to mitigate climate change (average value > 3.5). However, students were mostly well aware of the causes and impacts that are common and direct. Students did not have a good understanding of the causes related to food production and consumption. Students also did not know how climate change can affect social issues such as conflict and war issues, or inequality in income and gender. Among the three faculties, students of the FES had a better awareness of the causes and impacts of climate change but were less aware of the actions to mitigate climate change. Internet and television/radio were the main sources of information about climate change for students ( $88 \%$ and $61 \%$, respectively). This study showed that it is necessary to increase the provision of information related to climate change through the media as well as to integrate climate change knowledge into training programs at all levels from high school to university to improve the students' perceptions of climate change.
\end{abstract}

\section{Keywords}

Climate change, perception, university students, Vietnam National University of Agriculture

Received: September 30, 2020 Accepted: April 28, 2021

Correspondence to ntbyen@vnua.edu.vn

\section{Introduction}

Climate change is one of the biggest environmental concerns at a global scale in this century. Climate change is a long-term shift in 
global or regional climate patterns including temperature, precipitation, and wind. The observed changes in climate since the early $20^{\text {th }}$ century are primarily caused by the increase in the concentration of greenhouse gases (GHGs) in the atmosphere from human activities, particularly fossil fuel burning (IPCC, 2007). The headline statements of the AR5 synthesis report of the IPCC (2014a) confirmed that "human influence on the climate system is clear, and recent anthropogenic emissions of greenhouse gases are the highest in history. Recent climate changes have widespread impacts on human and natural systems". This report showed "that continued emission of greenhouse gases will cause further warming and longlasting changes in all components of the climate system, increasing the likelihood of severe, pervasive, and irreversible impacts for people and ecosystems. Limiting climate change would require substantial and sustained reductions in greenhouse gas emissions which, together with adaptation, can limit climate change risks". The Paris Agreement was introduced in 2015 to enhance the global response to climate change with the goal of keeping the global temperature increase to no more than $2.0^{\circ} \mathrm{C}$ compared to preindustrial levels and pursuing efforts to limit the temperature rise even further to $1.5^{\circ} \mathrm{C}$. The special report of the IPCC (2018b) highlights a number of climate change impacts that could be avoided by limiting global warming to $1.5^{\circ} \mathrm{C}$. In order to obtain this goal, global net emissions of carbon dioxide from human activities need to fall by about 45 percent from 2010 levels by 2030 , reaching 'net zero' by 2050 . This would require "rapid and far-reaching" transitions in land, energy, industry, buildings, transport, and cities.

Secretary-General Antonio Guterres, who hosted the 2019 Climate Action Summit, stated that "We are in the middle of a climate crisis. But we have the international frameworks, technology, and human and financial capital to solve the problem. We must act now" (UNDP, 2019). However, the report of the WMO (2019) showed that the global average temperature in the five year period from 2015 to 2019 increased by $1.1^{\circ} \mathrm{C}$ compared to the pre-industrial period. The impacts of climate change, such as sea-level rise, ice loss, and extreme weather, increased during this period. The concentration of carbon dioxide in the atmosphere has also increased to new records, with the growth rates nearly $20 \%$ higher than the previous five years. Dramatic strengthening of the Nationally Determined Contributions (NDCs) is needed to achieve the goals of the Paris Agreement. Countries must increase their NDC ambitions threefold to achieve the well below $2^{\circ} \mathrm{C}$ goal and more than fivefold to achieve the $1.5^{\circ} \mathrm{C}$ goal (UN, 2019).

Vietnam is one of the most vulnerable countries to the effects of climate change. Despite this, Vietnam has been actively working with the international community to protect Earth's climate system through the initiation of actions to reduce GHG emissions, and is working towards developing a low-carbon economy to achieve the Sustainable Development Goals to 2030. However, at present, the low carbon economy and green growth in Vietnam have not yet become the leading trends in sustainable development, while the mitigation of GHG emissions and increased GHG uptake will be mandatory from 2021 as stated by the country's commitment in the Paris Agreement. According to the conclusions of the Workshop on Assessing the Implementation of the Climate Change Strategy and Action Plan in Hanoi on May 22, 2020 , ten groups of solutions have been set up to accelerate the implementation of the National Strategy on Climate Change in the period of 2021-2030. The group of solutions mentioned first is related to the issue of raising public awareness about climate change responses, and turning awareness into specific actions in responding to climate change (MONRE, 2020).

As public perceptions, awareness, and knowledge of climate change play very important roles in future developments and environmental policies, there have been many studies conducted on these areas in recent times (Lorenzoni \& Pidgeon, 2006; Lorenzoni et al., 2007; Lee et al., 2015; Ojomo et al., 2015; Shi et al., 2015; Sulistyawati et al., 2018; Akrofi et al., 2019; Knutti, 2019; Kwon et al., 2019; Cordero et al., 2020; Giuseppe La et al., 2020; Lee et al., 2020). Education is an essential measure to increase peoples' awareness on the causes and 
impacts of climate change and thus, it will help increase the engagement of the community in climate action to tackle climate change. Unesco (2017) stated that "Education is a key vector to prepare societies for global changes. It plays a critical role in achieving sustainable development goals and putting into practice a global agreement on climate change. Education plays a paramount role in raising awareness and promoting behavioral change for climate change mitigation and adaptation. It helps increase the climate change mitigation and adaptation capacity of communities by enabling individuals to make informed decisions". The aim of this study was to evaluate the perceptions of climate change (causes, impacts, and climate actions) of undergraduate students at Vietnam National University of Agriculture (VNUA). Students' information sources were also studied to suggest effective methods to improve students' awareness of climate change. Differences in perceptions among students due to differences in gender, faculties, and study year levels were also accounted for this study.

\section{Methodology}

The study applied a quantitative approach and was conducted at VNUA from August to October 2019. The respondents were composed of 276 undergraduate students from three faculties, viz. the Faculty of Environmental Sciences (FES), the Faculty of Agronomy (FA), and the Faculty of Economics and Rural Development (FERD). The reason for choosing these three faculties was because they represent the main fields of training at the university (engineering, socio-economics, and environmental sciences). To see how study progress impacted differences in climate change awareness of the students, first- and fourth-year students in each of the three faculties were selected for the study. Detailed information about the student samples is presented in Table $\mathbf{1}$.

Because it was easy to access a large number of students at the same time (i.e. during lecture hours in the lecture hall), self-administered questionnaires were applied in this study following the similar studies of Ojomo et al. (2015) and Mugambiwa \& Dzomonda (2018). The structured questionnaire from the study of Akrofi et al. (2019) was modified and used in this study. Part I collected general information about the respondents. Part II dealt with students' perceptions of the causes, impacts, and actions related climate change. Part III gathered data on the sources of climate change information. Part II included five-point Likert-type statements which are described in detail in Table 2 . Respondents were asked to indicate the extent to which they agreed or disagreed with these statements. There were two types of statements, a positive type (statements without an asterisk in Table 2; the more a student agreed, the better their knowledge on climate change) and a

Table 1. Distribution of the numbers of students sampled according to their faculty, study year, and gender

\begin{tabular}{|c|c|c|c|}
\hline Items & Male & Female & Total \\
\hline \multicolumn{4}{|l|}{ Faculty of Environmental Sciences } \\
\hline First-year students* & 16 & 10 & 26 \\
\hline Fourth-year students & 14 & 36 & 50 \\
\hline \multicolumn{4}{|l|}{ Faculty of Agronomy } \\
\hline First-year students & 15 & 35 & 50 \\
\hline Fourth-year students & 23 & 27 & 50 \\
\hline \multicolumn{4}{|l|}{ Faculty of Economics and Rural Development } \\
\hline First-year students & 21 & 29 & 50 \\
\hline Fourth-year students & 12 & 38 & 50 \\
\hline Total & 101 & 175 & 276 \\
\hline
\end{tabular}

Note: There were only 26 students enrolled in the Faculty of Environmental Sciences as first-year students in the 2019-2020 academic year. 
Table 2. Five-point Likert-type statements ${ }^{1}$ for evaluating students' perceptions of climate change

\begin{tabular}{|c|c|}
\hline $\begin{array}{l}\text { Aspects of climate } \\
\text { change }\end{array}$ & Statements \\
\hline \multirow{10}{*}{$\begin{array}{l}\text { Causes of climate } \\
\text { change }\end{array}$} & Increase in greenhouse gases in the atmosphere \\
\hline & Deforestation \\
\hline & Using fossil fuels \\
\hline & Industrialization \\
\hline & Increase in the number of vehicles using fossil fuels such as cars and motorcycles \\
\hline & More garbage/improper waste disposal \\
\hline & Using firewood as fuel for cooking \\
\hline & Eating too much meat \\
\hline & Agricultural production (i.e. livestock raising, fertilizer use, rice production) \\
\hline & Climate change is only a natural fluctuation in temperature (not due to human activities) ${ }^{*}$ \\
\hline \multirow{12}{*}{$\begin{array}{l}\text { Impacts of climate } \\
\text { change }\end{array}$} & Droughts and heatwaves \\
\hline & Water supply and water quality \\
\hline & Renewable energy sources \\
\hline & Sea-level rise \\
\hline & Ocean acidification \\
\hline & Flooding \\
\hline & Reduction of crop yields and increased food insecurity \\
\hline & Biodiversity loss \\
\hline & Increase in health risks due to extreme temperatures \\
\hline & Increase in conflicts and wars \\
\hline & Gender and income inequalities \\
\hline & Reduction in the quality of life of future generations \\
\hline \multirow{9}{*}{ Climate actions } & Each individual can do something to minimize the impact of climate change \\
\hline & Using renewable energy helps to reduce climate change \\
\hline & Climate change is inevitable in this modern society \\
\hline & In my daily life, I do nothing to contribute to climate change* \\
\hline & In my daily life, I do nothing to reduce climate change* \\
\hline & $\begin{array}{l}\text { There is no reason to change our daily lifestyle because we are not sure of the consequences of climate } \\
\text { change }^{*}\end{array}$ \\
\hline & Living for today is more important than worrying about the future impacts of climate change ${ }^{*}$ \\
\hline & The government is primarily responsible for mitigating climate change ${ }^{*}$ \\
\hline & It is too late to do something about climate change* \\
\hline
\end{tabular}

Note: ${ }^{1}$ Statements without an asterisk belong to the positive type with a five-point scale of strongly disagree (1) to strongly agree (5) while those with an asterisk belong to the negative type with a five-point scale of strongly disagree (5) to strongly agree (1).

negative type (statements with an asterisk in Table 2; the more a student agreed, the poorer their knowledge on climate change).

Pre-tests of the questionnaire were conducted to ensure that students would understand the questions and statements. The final version of the questionnaire was distributed to the target students who were willing to be involved in the survey right after class hours in lecture rooms.

Data analysis included descriptive statistics and ANOVA tests using the statistical package for the social sciences (SPSS) version 20.

\section{Results and Discussion}

\section{Students' perceptions of the causes of climate change}

Students' perceptions of the causes of climate change were assessed based on their answers to the ten statements listed in Table 2. Figure 1 compares in detail the perceptions of each statement while Table 3 shows the general perceptions by gender, faculty, and year level based on the average values of the ten statements about the causes of climate change. The results showed that students generally had a high level 

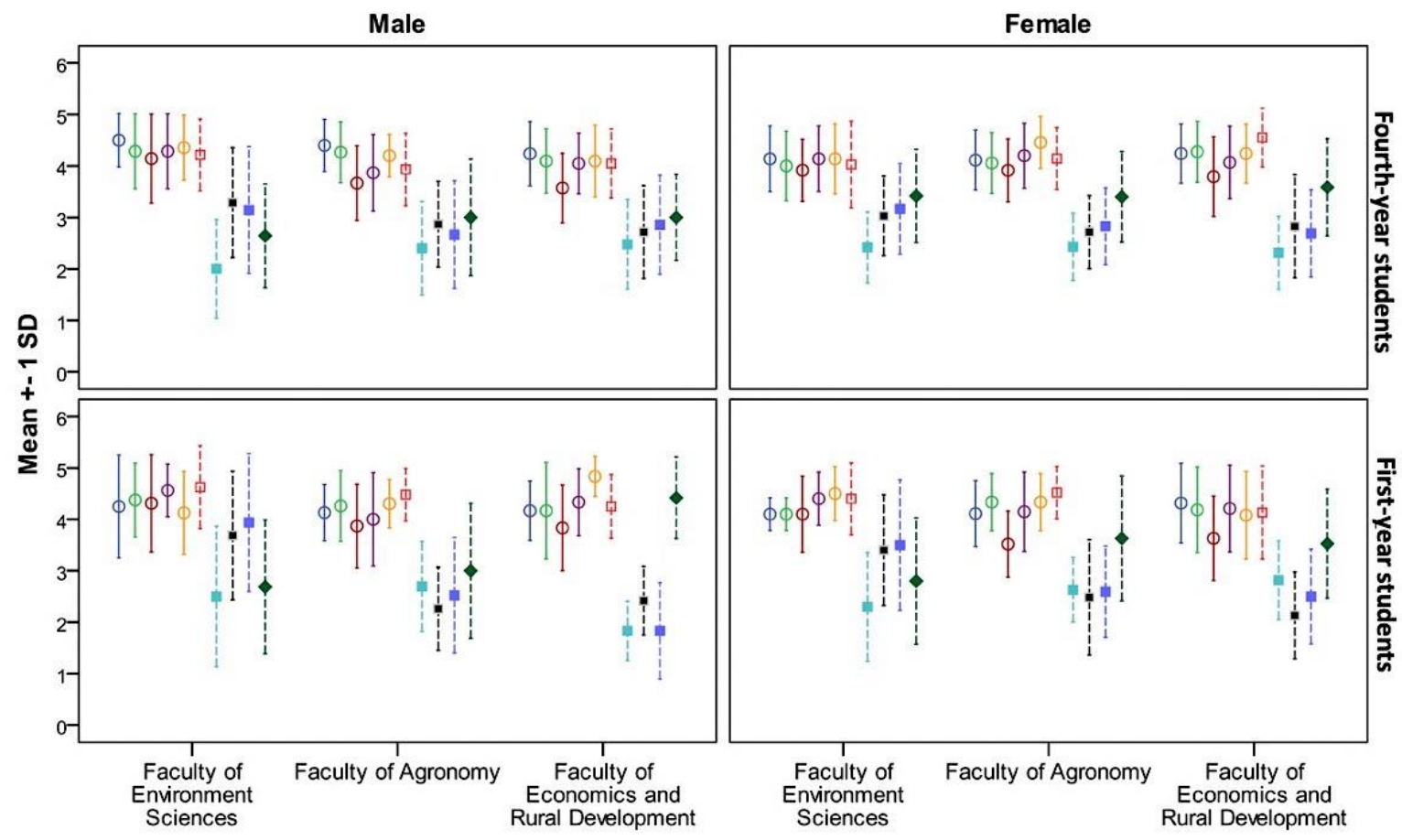
I Increase in greenhouse gases in the atmosphere (1)
I Deforestation (2)
I Using fossil fuels (3)
I Industrilization (4)
Increase the number of vehicles using fossil fuels such as cars and motorcycles (5)

\footnotetext{
1. More garbage/improper waste disposal (6)

Using firewood as fuel for cooking (7)

I. Eating too much meat (8)

I. Agricultural production (livestock raising, fertilizer use and rice production) (9)

7. Climate change is only a natural fluctuation in temperature (10)
}

Note: The mean was measured on a five-point scale with ascending magnitude from strongly disagree (1) to strongly agree (5) except for statement 10 with descending magnitude from strongly disagree (5) to strongly agree (1); the higher the mean value, the better the knowledge of the causes of climate change.

Figure 1. Students' views of each statement about the causes of climate change according to gender, faculty, and year level of study

of awareness about the causes of climate change (average value $>3.5$ ). There was no difference in awareness level by gender $(P=0.631)$ or by year level $(P=0.628)$, while there was a difference among faculties $(P=0.005)$. Students in the FES had a greater awareness than those in the FA and the FERD (Table 3). The survey results of Thang et al. (2013), who examined the causes of climate change in six faculties at VNUA, including the FES and FA, also showed that the FES students were better informed than students of other faculties.

Students generally had a good knowledge of the causes of climate change that are widely disseminated in the media, as well as in the curriculum from high school. When looking at the details of the students' views for each statement, all the students had the same high level (small SD) of perception of the causes of climate change including (1) due to the increase in greenhouse gases (statement 1); (2) due to deforestation (statement 2); and (3) due to the use of fossil fuels, industrialization, and an increase in transportation (statements 3, 4, and 5). The current increase in greenhouse gas emissions is mainly caused by the increase in $\mathrm{CO}_{2}$ emissions resulting from the use of fossil fuels and deforestation. Using fossil fuels will release $\mathrm{CO}_{2}$ 
Table 3. Mean, standard deviations (SD), and ANOVA test of scales of the students' overall perceptions of the causes of climate change according to gender, faculty, and year level of study

\begin{tabular}{|c|c|c|c|c|}
\hline Items & $\mathrm{n}$ & Mean $^{1}$ & SD & $P$-value \\
\hline \multicolumn{5}{|l|}{ Gender } \\
\hline Male & 101 & 3.75 & 0.392 & \multirow{2}{*}{0.631} \\
\hline Female & 175 & 3.72 & 0.374 & \\
\hline \multicolumn{5}{|l|}{ Faculty } \\
\hline Faculty of Environment Sciences & 76 & 3.85 & 0.418 & \multirow{3}{*}{0.005} \\
\hline Faculty of Agronomy & 100 & 3.69 & 0.318 & \\
\hline Faculty of Economics and Rural Development & 100 & 3.69 & 0.391 & \\
\hline \multicolumn{5}{|l|}{ Year of study } \\
\hline First-year students & 126 & 3.72 & 0.417 & \multirow{2}{*}{0.628} \\
\hline Fourth-year students & 150 & 3.73 & 0.347 & \\
\hline
\end{tabular}

Note: ${ }^{1}$ Mean was measured on ten statements related to the causes of climate change (listed in Table 2) with a five-point scale. The higher the mean value, the better the perception of the causes of climate change: 4.51-5.00-very good perception; 3.51-4.50good perception; 2.51-3.50-moderate perception; 1.51-2.50-poor perception; 1.00-1.50-very poor perception.

directly into the atmosphere, while the reduced forest area due to deforestation will reduce the area of the $\mathrm{CO}_{2}$ sequestration reservoirs.

However, students had poor knowledge of other causes of climate change, especially those related to greenhouse gas emissions from firewood used as fuel, food consumption, and agricultural production (statements 7, 8, \& 9) (Figure 1). In these statements, the standard deviation also tended to be higher, reflecting the heterogeneity of the perceptions of the causes of climate change. The differences in student perceptions according to the faculties as analyzed in Table 3 can be seen mainly from these statements. Students of the FERD had the poorest awareness, followed by students of the FA. Firstyear students tended to have poorer awareness than fourth-year students.

Students were generally inclined to disagree that using firewood as fuel for cooking causes climate change (average value $<3$; statement 7 ). First-year students had a lower level of agreement than fourth-year students (lower average value). In fact, there is still much debate about the use of firewood and climate change. Burning wood is often thought to be carbon neutral, and so this is a climate-friendly way of using heat. This is based on the assumption that the amount of $\mathrm{CO}_{2}$ released during burning will be isolated and sequestrated into growing trees when biomass is taken from sustainably managed forests (Koponen et al., 2018). As a result, the amount of $\mathrm{CO}_{2}$ emitted from the wood-burning process is usually zero in life cycle evaluation studies (Cherubini et al., 2011). However, it has been shown that there is a time lag between $\mathrm{CO}_{2}$ emissions and carbon sequestration when planting. In addition, burning firewood in a house (domestic heaters) emits methane and black carbon which increase global warming. Research by Robinson (2011) indicated that indoor firewood use causes greater global warming than gas. Savolahti et al. (2019) also confirmed the use of firewood in residential areas in Finland as a major source of climate-impacting emissions, like short-lived climate forcers (SLCF) and biogenic $\mathrm{CO}_{2}$. In particular, SLCF emissions from firewood burning cause a more significant warming impact compared to GHGs.

Food consumption and agricultural production, which are related to statements 8 and 9 , are also sources of GHG emissions causing climate change. However, students had very poor awareness of this knowledge (average value $<3$ ). Similar results were found through student survey results in Africa (Akrofi et al., 2019) and in Bangladesh (Kumar et al., 2019). In particular, students in the FERD and FA had lower levels of awareness than the FES students $(P<0.001)$; and first-year students in these two faculties had 
lower levels of awareness compared to the fourth-year students. Food production contributes up to $26 \%$ of global anthropogenic GHG emissions (Ritchie, 2019), of which, livestock supply chains account for $14.5 \%$ (7.1 gigatons $\mathrm{CO}_{2}$-eq per annum). Cattle (beef, milk) contribute the largest emissions (65\%) largely due to methane emissions resulting from rumen fermentation. While pig meat and poultry meat and eggs also contribute a significant amount of emissions (Gerber et al., 2013). According to Van De Kamp et al. (2018), reducing red and processed meat consumption during dinner will significantly lower dietary GHG emissions of people in the Netherlands. GHGs are emitted directly through crop production activities such as the release of nitrous oxide from the use of fertilizers and manure, and methane emissions from rice production. Thus, reducing the consumption of meat and the application of best practices in crop production could contribute to climate change mitigation.

Students were well aware of the relationship between domestic waste and climate change (the average value > 4.0). This may be due to the problem of plastic waste that has been mentioned a lot in the media in recent years. According to Ackerman (2000), waste management contributes to the level of greenhouse emissions in different aspects including (1) methane emissions from landfills; (2) recycling and waste reduction leading to reduced energy use for waste treatment; (3) energy recovery from waste; (4) reduction in demand for virgin paper and thus decreases in deforestation; and (5) energy used in the long-distance transport of waste. Plastics like shopping bags and water bottles are used on a daily basis, resulting in a total production of 8.3 billion metric tons of plastic worldwide from 1950 to 2017. Of this amount, most plastics are only used once and are then immediately discarded, usually into landfills (Wang, 2020). The production and incineration of plastic will emit more than 850 million metric tons of greenhouse gases to the atmosphere, equal to the emissions from 189 five-hundred-megawatt coal power plants (Ciel, 2019).

Surprisingly, while most students thought that deforestation and fossil fuel use caused climate change, they still assumed that climate change was just a natural fluctuation (average value < 3.5). However, the views on this issue were quite different among the students interviewed as expressed by a high SD. In general, students of the FES had the poorest awareness of this issue compared to the other two faculties $(P<0.05)$. When looking at aspects of gender and study year level, the first-year male students in the FERD showed a higher level of awareness (average score $>4$ ) with a relatively small SD compared to the other student groups.

According to Shi et al. (2015), causal knowledge significantly contributes to people's concerns about climate change and their willingness to support climate-friendly policies. Therefore, it is important to increase VNUA students' awareness of the causes of climate change, especially those related to food consumption and production.

\section{Students' perceptions of the impacts of climate change}

Twelve five-point Likert-type statements were used to assess the students' perceptions of the impacts of climate change (Table 2, Figure 2). Their perceptions were generally at a good level (average value was close to 4.0) and there were no statistically significant differences in awareness among students surveyed by gender, faculty, and year level (Table 4). However, students of the FES tended to perceive the impacts better than the FA and FERD students (average value of 4.02 vs. 03.87 and 3.92, respectively; $P=0.054$ ). When we look in more detail at each of the statements about the impacts of climate change, we can see that there was a difference in awareness level for each statement group (Figure 2). Students were well aware of the relatively common impacts of climate change such as impacts on (1) the environment that are mentioned relatively frequently (statements 1-6) such as droughts, heatwaves, sea-level rise, decreases in water supply and water quality, and flooding; and (2) biology (statements 7-9) such as the reduction of crop yields and biodiversity loss, but they did not have much knowledge about the impacts of climate change on the social 


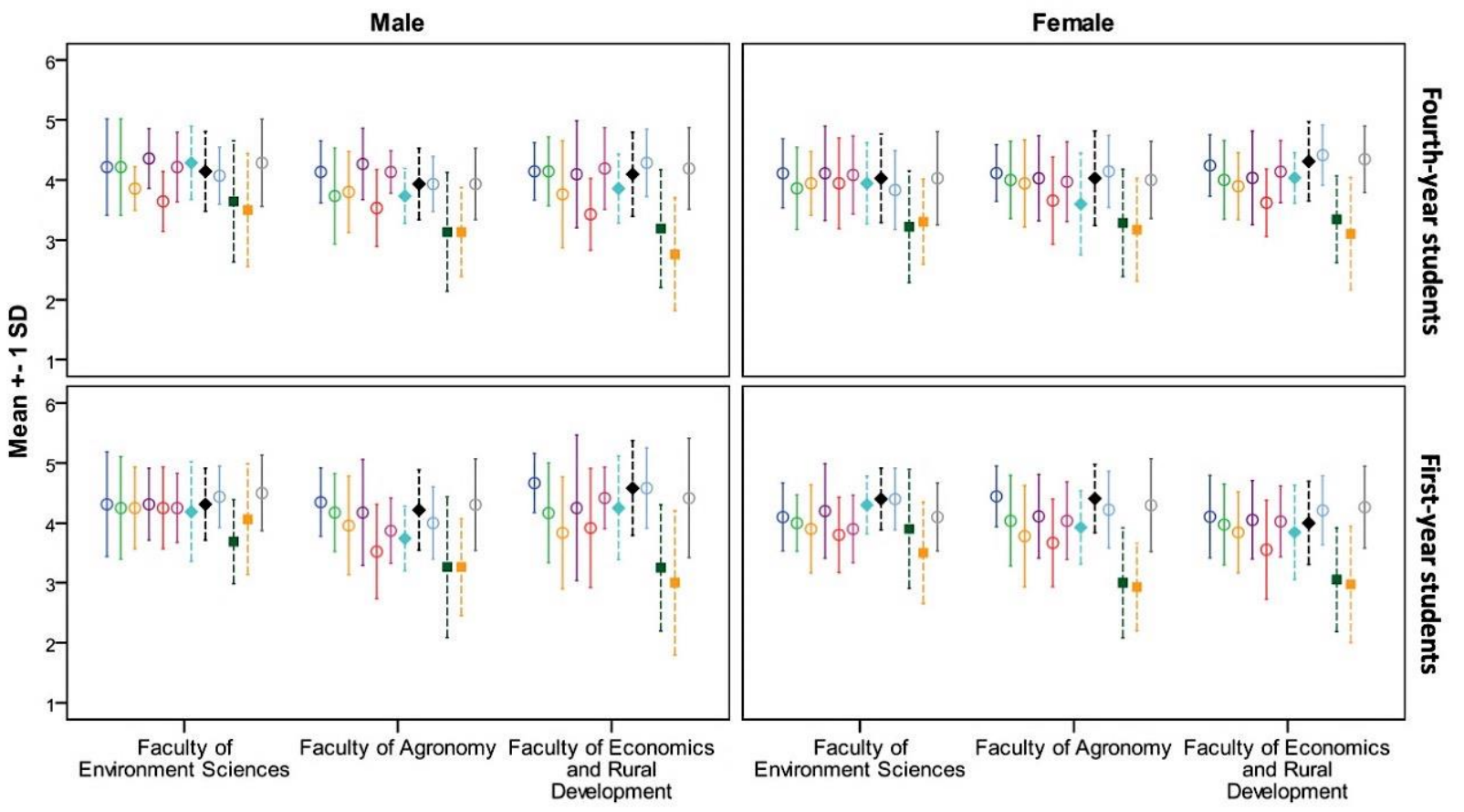

I Droughts and heat waves (1)

I Impacts on water supply and water quality (2)

Affects renewable energy sources (3)

I Sea level rise (4)

I Ocean acidification (5)

I Flooding (6)

Reduction of crop yields causing food insecurity (7)

I. Biodiversity loss (8)

Increase in health risks due to extreme temperatures (9)

I. Increase in conflicts and wars (10)

I. Gender and income inequalities (11)

I Reduction in the quality of life of future generations (12)

Note: The mean was measured on a five-point scale with ascending magnitude from strongly disagree (1) to strongly agree (5); the higher the mean value, the better the knowledge of the impacts of climate change.

Figure 2. Students' views of each statement about the impacts of climate change according to gender, faculty, and year level of study

sector as shown in statement 10 (climate change increases conflicts and wars) and statement 11 (climate change causes gender and income inequalities). Literature has shown that climate change can increase conflicts and wars due to the scarcity of natural resources (Bowles et al., 2015; Akresh, 2016), and social inequality (Desa, 2017; Diffenbaugh \& Burke, 2019). With these two statements, students of the FES also tended to have a firmer grasp in comparison with the FA and FERD students $(P<0.001)$.

Statements 1-9 are about the effects of climate change mentioned relatively frequently in the media. In addition, many extreme events are also associated with daily life such as heat, droughts, and floods. Along with the impacts related to the oceans, students strongly agreed that climate change leads to sea-level rise. However, students were only at an average level of awareness of the connection between climate change and ocean acidification (statement 5). Increases in the $\mathrm{CO}_{2}$ concentration in the atmosphere due to human activities not only causes increases in global warming but also ocean acidification (Turley \& Findlay, 2009; Leton et al., 2018; Ucsusa, 2019). Ocean acidification reduces the availability of carbonate ions, key building blocks of skeletons and shells. This makes organisms with shells and skeletons, such as clams, mussels, crabs, phytoplankton, and corals, have significantly reduced chances for their offspring to survive (Ucsusa, 2019). According to the IPCC (2014b), warming 
Table 4. Mean, standard deviations (SD), and ANOVA test of scales of the students' overall perceptions of the impacts of climate change according to gender, faculty, and year level of study

\begin{tabular}{|c|c|c|c|c|}
\hline Items & $\mathrm{n}$ & Mean $^{1}$ & SD & $p$-value \\
\hline \multicolumn{5}{|l|}{ Gender } \\
\hline Male & 101 & 3.98 & 0.41 & \multirow{2}{*}{0.083} \\
\hline Female & 175 & 3.90 & 0.39 & \\
\hline \multicolumn{5}{|l|}{ Faculty } \\
\hline Faculty of Environment Sciences & 76 & 4.02 & 0.41 & \multirow{3}{*}{0.054} \\
\hline Faculty of Agronomy & 100 & 3.87 & 0.41 & \\
\hline Faculty of Economics and Rural Development & 100 & 3.92 & 0.36 & \\
\hline \multicolumn{5}{|l|}{ Year of study } \\
\hline First-year students & 126 & 3.90 & 0.38 & \multirow{2}{*}{0.125} \\
\hline Fourth-year students & 150 & 3.97 & 0.41 & \\
\hline
\end{tabular}

Note: ${ }^{1}$ Mean was measured on 10 statements related to the impacts of climate change (listed in Table 2) with a five-point scale. The higher the mean value, the better the perception of the impacts of climate change: 4.51-5.00-very good perception; 3.51-4.50-good perception; 2.51-3.50-moderate perception; 1.51-2.50-poor perception; 1.00-1.50-very poor perception.

temperatures together with declining $\mathrm{pH}$ and carbonate ion concentrations in seawater, present risks to fisheries and aquaculture in terms of productivity and regional livelihood security. Students of the FES had a better understanding of this issue than those of other faculties $(P<$ 0.01 ), especially first-year male students and fourth-year female students. This indicated that the FES students tended to be more concerned about climate change; however, the inequality between male and female students and between the year levels showed that the students' level of awareness depended on their gender and year level of study.

\section{Students' perspectives of climate actions}

Students' awareness of climate change mitigation was evaluated based on nine statements (Table 2, Figure 3). Table 5 shows the general perceptions by gender, faculty, and year based on the average values of the nine statements. Similar to the awareness about the causes and impacts of climate change, students were also well aware of climate action (mean value > 3.5). Female students had a higher level of awareness than male ones (3.95 vs. 3.7; $P=$ 0.000). Surprisingly, among the three faculties, students of the FES had a higher level of understanding of the causes of climate change and its impacts (indicated in Tables $\mathbf{3}$ and 4 ) but had the poorest attitude towards actions for reducing climate change. The perception average value of the FES was 3.52, while those of the FA and FERD were 3.95 and 4.04, respectively $(P<$ 0.001) (Table 5). Thus, it can be seen that the level of awareness of climate actions does not depend entirely on knowledge of climate change. According to Lorenzoni \& Pidgeon (2006), although there is widespread concern about climate change, it is only considered a secondary issue compared to other important issues in daily life. For students of the FES, they may argue that there are more important environmental issues that need to be addressed, especially in the context of Vietnam.

Out of the nine statements related to climate action, students were more concerned with the first three statements, especially regarding the perspective of "each individual can do something to minimize the impact of climate change" (Figure 3). However, many students believed that individuals do not contribute to climate change (statement 4) and have done nothing so far to mitigate climate change (statement 5), especially for students of the FES (average value $<3.0$ for male students and $<3.5$ for female students). The average value of statement 8 was also relatively low $(<3.5)$ revealing that students thought that the responsibility for climate change mitigation belongs to the government and not individuals, even though they knew that everyone can do something to mitigate climate 

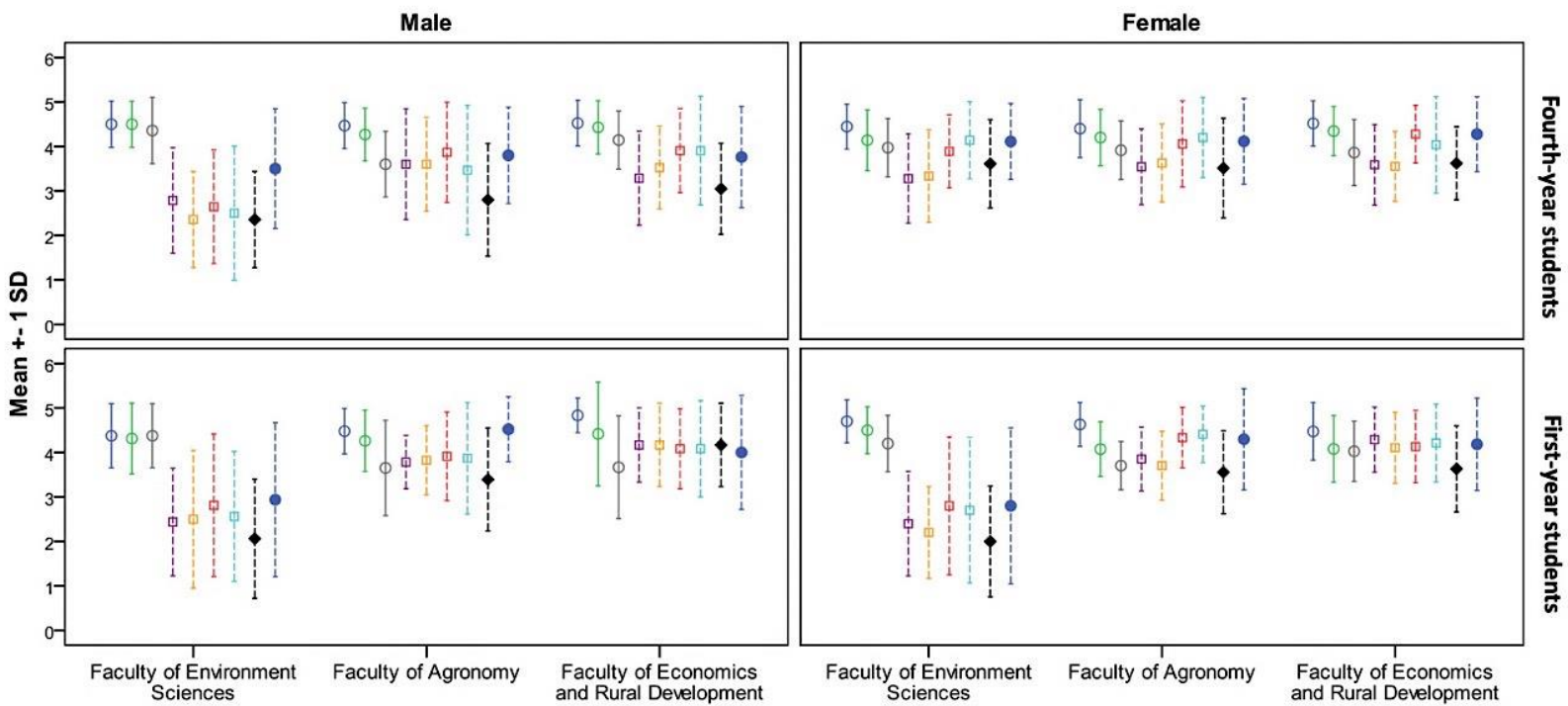

Tach individual can do something to minimize the impact of climate change (1)

I Using renewable energy helps to reduce climate change(2)

I Climate change is inevitable in this modern society (3)

I. In my daily life, I do nothing to contribute to climate change (4)

I. In my daily life, I do nothing to reduce climate change (5)

T. There is no reason to change our daily lifestyle because we are not sure of the consequences of climate change (6)

Living for today is more important than worrying about the future impacts of climate change (7)

]. The government is primarily responsible for mitigating climate change (8)

I. It is too late to do something about climate change (9)

Note: The mean was measured on a five-point scale with ascending magnitude from strongly disagree (1) to strongly agree (5) for statements from 1-3 while with descending magnitude from strongly disagree (5) to strongly agree (1) for statements from 4-9; higher mean values indicate a better attitude towards climate change mitigation.

Figure 3. Students' views of each statement about the climate actions according to gender, faculty, and year level of study

Table 5. Mean, standard deviations (SD), and ANOVA test of scales of the students' overall perspectives of climate actions according to gender, faculty, and year level of study

\begin{tabular}{|c|c|c|c|c|}
\hline Items & $\mathrm{n}$ & Mean $^{1}$ & SD & $p$-value \\
\hline \multicolumn{5}{|l|}{ Gender } \\
\hline Male & 101 & 3.70 & .683 & \multirow{2}{*}{0.000} \\
\hline Female & 175 & 3.95 & .683 & \\
\hline \multicolumn{5}{|l|}{ Faculty } \\
\hline Faculty of Environment Sciences & 76 & 3.52 & .687 & \multirow{3}{*}{0.000} \\
\hline Faculty of Agronomy & 100 & 3.95 & .465 & \\
\hline Faculty of Economics and Rural Development & 100 & 4.04 & .478 & \\
\hline \multicolumn{5}{|l|}{ Year of study } \\
\hline First-year students & 126 & 3.84 & .533 & \multirow{2}{*}{0.537} \\
\hline Fourth-year students & 150 & 3.89 & .631 & \\
\hline
\end{tabular}

Note: ${ }^{1}$ Mean was measured on ten statements related the actions for climate change (listed in Table 2) with a five-point scale. Higher mean values indicate a better attitude on climate change mitigation: 4.51-5.00-very good perception; 3.51-4.50-good perception; 2.51-3.50-moderate perception; 1.51-2.50-poor perception; 1.00-1.50-very poor perception. 
change (statement 1). The survey results also suggested that students from the FERD and FA were relatively optimistic about the climate actions that they can take to minimize the impacts of climate change in the future (average value of statement $9>4.0$ ). Students of the FES were less optimistic, especially first-year students (average value < 3.0 ). The differences in the levels of awareness among the FES students were also noticeable, especially for first-year students, which were indicated by large SDs for statements 4-9.

In order to avoid risks and the impacts of climate change, the Paris Agreement was adopted at the Paris Climate Conference (COP21) in 2015 with the goals of limiting global warming above pre-industrial levels to well below $2^{\circ} \mathrm{C}$ and pursuing efforts to limit it to $1.5^{\circ} \mathrm{C}$ at the end of this century. According to the IPCC (2018a), to obtain this goal, the cumulative amount of $\mathrm{CO}_{2}$ emissions from 2018 onwards needs to remain below a carbon budget of 420 $\mathrm{GtCO}_{2}$. There are a multitude of potential pathways for reducing $\mathrm{GHG}$ emissions consistent with the $1.5^{\circ} \mathrm{C}$ goal, which can be identified under a range of assumptions about economic growth, technology developments, and lifestyles. However, there are challenges to achieve the $1.5^{\circ} \mathrm{C}$ pathways due to the lack of global cooperation, lack of governance of the required energy and land transformations, and increases in resource-intensive consumption (IPCC, 2018a). According to the report of the UN (2019), the required cuts in emissions are now 7.6 percent per year on average for the $1.5^{\circ} \mathrm{C}$ goal while it was 3.3 percent with serious climate actions implemented in 2010. Obviously, greater cuts will be needed the longer those actions are delayed. Changing one's lifestyle can contribute to large reductions in the emissions of GHGs. According to Cafaro (2011), individuals can save as much as $15 \mathrm{GtCO}_{2}$ simply by changing their diet to avoid meat, or by forgoing air travel. The VNUA students thought that climate change is a social problem, probably because most of them have not felt the direct impacts of climate change.

\section{Students' information sources about climate change}

The survey results showed that the students' main sources of information about climate change were the internet $(88 \%)$ and television/radio $(61 \%)$. This result is understandable in the era of industry 4.0. According to statistics in 2019, almost 64 million people in Vietnam (accounting for 64\% of the population) use the internet with an average of nearly 7 hours a day through smartphones (Vnetwork, 2019). Television/radio is also a very popular form of media, which almost every family now has access to. This shows that digital media play an important role in the dissemination of information about climate change.

In order for students to be able to apply the basic knowledge of climate change in deciding mitigation and adaptation measures to climate change within their field of study, it is necessary to integrate the teaching and research activities of the faculty. This was also mentioned in the studies of Filho \& Hamstock (2019) and Lehtonen et al. (2019). As such, the national target program on climate change launched an activity to develop a comprehensive project integrating climate change response contents in education programs (MONRE, 2007). However, the information sources of high school and university were not as common in the current study, accounting for $30 \%$ and $33 \%$, respectively. The percentages of FES students who reported high school and/or university as sources of information were higher than those of other faculties, especially for first-year students (Table 6). This suggests that the FES training program may have recently begun focusing more on integrating information related to climate change in the teaching process but the effectiveness is still low.

In practical conditions, integrating climate change knowledge into the current education system requires a review of existing methods and the development of a system to equip learners with the skills, knowledge, and attributes necessary to cope with future challenges (Bangay \& Blum, 2010). According to Hess \& Collins (2018), there are three ways to effectively 
Table 6. Students' information sources about climate change according to faculty and college year (\% of students)

\begin{tabular}{|c|c|c|c|c|c|c|c|}
\hline \multirow{2}{*}{ Information sources about climate change } & \multicolumn{2}{|c|}{ Faculty of Environment } & \multicolumn{2}{|c|}{ Faculty of Agronomy } & \multicolumn{2}{|c|}{$\begin{array}{c}\text { Faculty of Economics } \\
\text { and Rural } \\
\text { Development }\end{array}$} & \multirow{2}{*}{ Overal } \\
\hline & $\begin{array}{l}\text { First-year } \\
\text { students }\end{array}$ & $\begin{array}{l}\text { Fourth- } \\
\text { year } \\
\text { students }\end{array}$ & $\begin{array}{l}\text { First- } \\
\text { year } \\
\text { students }\end{array}$ & $\begin{array}{l}\text { Fourth- } \\
\text { year } \\
\text { students }\end{array}$ & $\begin{array}{l}\text { First- } \\
\text { year } \\
\text { students }\end{array}$ & $\begin{array}{l}\text { Fourth- } \\
\text { year } \\
\text { students }\end{array}$ & \\
\hline Television/Radio & 60 & 58 & 74 & 56 & 64 & 52 & 61 \\
\hline Internet & 84 & 73 & 92 & 90 & 92 & 90 & 88 \\
\hline High school & 40 & 31 & 32 & 24 & 26 & 26 & 30 \\
\hline University & 58 & 35 & 40 & 18 & 30 & 20 & 33 \\
\hline Family/friends & 16 & 8 & 18 & 18 & 20 & 20 & 17 \\
\hline Local authorities & 16 & 4 & 24 & 8 & 20 & 22 & 17 \\
\hline
\end{tabular}

integrate climate science into training programs, namely (1) having a single core course about climate change that is a required course for all students; (2) having a high volume of options of climate-related courses offered in multiple departments, thus increasing the proportion of courses that cover climate change in the general education curriculum; and (3) having a menu of courses that would include climate-science or climate-change education for environmental or sustainability studies programs.

\section{Conclusions}

Surveyed students were generally well aware of the causes of climate change, the effects of climate change, and actions to mitigate climate change. However, the students were mostly well aware of the causes and impacts that are common and direct, which are mentioned relatively frequently in the media (e.g. causes of deforestation, use of fossil fuels, industrialization; impacts of droughts and heatwaves, floods, and water resources, etc.). Food consumption and agricultural production are GHG emission sources but students did not have a good understanding of the causes related to food production and consumption. Students also did not know how climate change can affect social issues such as conflict and war issues, and inequality in income and gender.

Comparing the students' awareness of climate change among the three faculties, students of the FES had a higher-level awareness of the causes and impacts of climate change but had a poorer level of perception of the actions to mitigate climate change. Many students in the FES still believed that individuals who did not contribute to climate change did not need to take actions to mitigate climate change and the responsibility rested with the government.

Internet and television/radio were the main sources of information about climate change of the students ( 88 and $61 \%$, respectively). Very few students thought that their sources of information about climate change came from high school (30\%) or university (33\%).

The results indicated that it is necessary to increase the provision of information related to climate change through the media as well as to integrate climate change knowledge into training programs at all levels from high school to university to improve the students' perceptions of climate change, particularly making students aware of causes related to food production and consumption, and the impact of climate change on social issues. Students also need to be provided with more information to better understand the individual's responsibility for climate change mitigation.

\section{References}

Ackerman F. (2000). Waste Management and Climate Change. Local Environment. 5(2): 223-229.

Akresh R. (2016). Climate Change, Conflict, and Children. The Future of Children. 26(1): 51-71.

Akrofi M. M., Antwi S. H. \& Gumbo J. R. (2019). Students in Climate Action: A Study of Some Influential Factors and Implications of Knowledge Gaps in Africa. 
Environments. $\quad 6(2): \quad 12 . \quad$ DOI: 10.3390/environments6020012.

Bangay C. \& Blum N. (2010). Education responses to climate change and quality: two parts of the same agenda? International Journal of Education Development 30: 335-450.

Bowles D. C., Butler C. D. \& Morisetti N. (2015). Climate change, conflict and health. Journal of the Royal Society of Medicine. 108(10): 390-395.

Cafaro P. (2011). Beyond business as usual: alternative wedges to avoid catastrophic climate change and create sustainable societies In: The Ethics of Global Climate Change. Arnold, D. (ed.). Cambridge University Press: 192-215.

Cherubini F., Peters G. P., Berntsen T., StrØMman A. H. \& Hertwich E. (2011). CO2 emissions from biomass combustion for bioenergy: atmospheric decay and contribution to global warming. GCB Bioenergy. 3(5): 413-426.

CIEL (2019). Plastic \& climate: the hidden costs of a plastic planet [Online]. Center for International Envirnomental Law. Retrieved from https://www.ciel.org/wpcontent/uploads/2019/05/Plastic-and-ClimateExecutive-Summary-2019.pdf on June 18, 2020.

Cordero E. C., Centeno D. \& Todd A. M. (2020). The role of climate change education on individual lifetime carbon emissions. PLOS ONE. 15(2): e0206266.

DESA 2017. Climate change and social inequality [Online]. Department of Economic \& Social Affairs, United Nation. Retrieved from https://www.un.org/esa/desa/papers/2017/wp152_201 7.pdf on July 20, 2020.

Diffenbaugh N. S. \& Burke M. (2019). Global warming has increased global economic inequality. Proceedings of the National Academy of Sciences. 116(20): 98089813.

Filho W. L. \& Hamstock S. L. (2019). Climate Change Education: An Overview of International Trends and the Need for Action. In: Climate Change and the Role of Education. Filho W. L. \& Hamstock S. L. (Eds.). Springer Nature Switzerland Switzerland: 1-17.

Gerber P. J., Steinfeld H., Henderson B., Mottet A., Opio C., Dijkman J., Falcucci A. \& Tempio G. (2013). Tackling climate change through livestock: a global assessment of emissions and mitigation opportunities [Online]. Rome: FAO. Retrieved from http://www.fao.org/3/a-i3437e.pdf on June 18, 2020.

Giuseppe La T., Alice De Paula B., Cristina S., Rosario Andrea C., Domenico B., Alice M. \& Angela Del C. (2020). Knowledge and perception about climate change among healthcare professionals and students: A cross-sectional study. South Eastern European Journal of Public Health (SEEJPH). DOI: 10.4119/seejph-3347(0).

Hess D. J. \& Collins B. M. (2018). Climate change and higher education: assessing factors that affect curriculum requirements. Journal of Clean Production. 170: $1451-1458$.

IPCC (2007). Climate Change 2007: Synthesis Report. Contribution of Working Groups I, II, and III to the Fourth Assessment Report of the Intergovernmental Panel on Climate Change.

IPCC (2014a). Climate Change 2014: Synthesis ReportContribution of Working Groups I, II and III to the Fifth Assessment Report of the Intergovernmental Panel on Climate Change.

IPCC (2014b). The Ocean. Climate change 2014: Impacts, Adaptation, and Vulnerability. Part B: Regional Aspects. Contribution of Working Group II to the Fifth Assessment Report of the Intergovernmental Panel on Climate Change. Cambridge, United Kingdom and New Your, NY, USA

IPCC (2018a). Mitigation Pathways Compatible with $1.5^{\circ} \mathrm{C}$ in the Context of Sustainable Development. Retrieved from

https://www.ipcc.ch/site/assets/uploads/sites/2/2019/0 2/SR15_Chapter2_Low_Res.pdf on June 20, 2020.

IPCC (2018b). Special report: Global warming of $1.5 \mathrm{oC}$. Retrieved from https://www.ipcc.ch/sr15/download/ on June 20, 2020.

Knutti R. (2019). Closing the Knowledge-Action Gap in Climate Change. One Earth. 1(1): 21-23.

Koponen K., Soimakallio S., Kline K. L., Cowie A. \& Brandão M. (2018). Quantifying the climate effects of bioenergy - Choice of reference system. Renewable and Sustainable Energy Reviews. 81: 2271-2280.

Kumar B., Asad A. I., Chandraayor B. \& Banik P. (2019). Perception and Knowledge on Climate Change: A Case Study of University Students in Bangladesh. Journal of Atmoshpheric Science Research. 2(3): 17-22.

Kwon S.-A., Kim S. \& Lee J. E. (2019). Analyzing the Determinants of Individual Action on Climate Change by Specifying the Roles of Six Values in South Korea. Sustainability. 11(7): 1834

Lee K., Gjersoe N., O'Neill S. \& Barnett J. (2020). Youth perceptions of climate change: A narrative synthesis. WIREs Climate Change. 11(3): e641.

Lee T. M., Markowitz E. M., Howe P. D., Ko C.-Y. \& Leiserowitz A. A. (2015). Predictors of public climate change awareness and risk perception around the world. Nature Climate Change. 5(11): 1014-1020.

Lehtonen A., Salonen A. O. \& Cantell H. (2019). Climate Change Education: A New Approach for a World of Wicked Problems. In: Cook J. W. (Ed.). Sustainability, Human Well-Being, and the Future of Education.Palgrave Macmillan, Cham: 339-374.

Leton A., Matear R. J. \& Mongin M. (2018). Effects of Climate Change on Oceaon Acidification Relevant to Pacific Islands. Pacific Marine Climate Change Report Card: Science Review: 31-42.

Lorenzoni I., Nicholson-Cole S. \& Whitmarsh L. (2007). Barriers perceived to engaging with climate change 
among the UK public and their policy implications. Global Environmental Change. 17(3): 445-459.

Lorenzoni I. \& Pidgeon N. F. (2006). Public Views on Climate Change: European and USA Perspectives. Climatic Change. 77(1): 73-95.

MONRE (2007). National target program to respond to climate change. Retrieved from https://www.thiennhien.net/wpcontent/uploads/2012/08/CTMTQG_27_07_08.pdf on July 10, 2020 (in Vietnamese).

MONRE (2020). National Strategy and Plan to Respond to Climate Change (in Vietnamese) [Online]. Retrieved from http://www.monre.gov.vn/Pages/danh-gia-chienluoc-va-ke-hoach-quoc-gia-ve-ung-pho-bien-doi-khihau.aspx on July 8, 2020.

Mugambiwa S. S. \& Dzomonda O. (2018). Climate change and vulnerability discourse by students at a South African university. Jamba (Potchefstroom, South Africa). 10(1): 476.

Ojomo E., Elliott M., Amjad U. \& Bartram J. (2015). Climate Change Preparedness: A Knowledge and Attitudes Study in Southern Nigeria. Environments. 2(4): 435-448.

Ritchie H. (2019). Food production is responsible for onequarter of the world's greenhouse gas emissions [Online]. Retrieved from https://ourworldindata.org/food-ghg-emissions on June 18, 2020.

Robinson D. L. (2011). Australian wood heaters currently increase global warming and health costs. Atmospheric Pollution Research. 2(3): 267-274.

Savolahti M., Karvosenoja N., Soimakallio S., Kupiainen K., Tissari J. \& Paunu V.-V. (2019). Near-term climate impacts of Finnish residential wood combustion. Energy Policy. 133: 110837. DOI: 10.1016/j.enpol.2019.06.045

Shi J., Visschers V. H. M. \& Siegrist M. (2015). Public Perception of Climate Change: The Importance of Knowledge and Cultural Worldviews. Risk Analysis. 35(12): 2183-2201.

Sulistyawati S., Mulasari S. A. \& Sukesi T. W. (2018). Assessment of Knowledge regarding Climate Change and Health among Adolescents in Yogyakarta, Indonesia. Journal of Environmental and Public Health. 2018: 1-7.

Nguyen Tat Thang, Tran Thi Ha Nghia, Nguyen Thi Ngoc Thuy, Nguyen Cong Uoc \& Bui Thi Hai Yen (2013). Perceptions of students of Hanoi University of Agriculture on climate change and its effects on the development of agriculture, forestry, fishery and people's lives in rural areas of Vietnam. Journal of Science. \& Development. 11(4): 582-592 (in Vietnamese).

Turley C. \& Findlay H. S. (2009). Chapter 21 - Ocean Acidification as an Indicator for Climate Change. In: Letcher T. M. (Ed.). Climate Change. Elsevier Amsterdam: 367-390.

UCSUSA (2019). CO2 and Ocean Acidification: Causes, Impacts, Solutions [Online]. Union of Concerned Scientists. Retrieved from https://www.ucsusa.org/resources/co2-and-oceanacidification\#: :text $=\mathrm{CO} 2 \% 20$ concentrations $\% 20$ driv e\%20rising,the \%20detriment $\% 20$ of $\% 20$ marine $\% 20$ ec osystems. on June 22, 2020.

UN (2019). Executive summary - Emissions Gap Report $2019 . \quad$ Retrieved from https://wedocs.unep.org/bitstream/handle/20.500.11822/ 30798/EGR19ESEN.pdf?sequence=13 on June 20, 2020.

UNDP (2019). The defining threat of our time [Online]. Retrieved from https://www.undp.org/content/undp/en/home/events/2 019/climate-2020.html on July 8, 2020.

UNESCO (2017). UNESCO, Climate Change Education and COP21 [Online]. Retrieved from https://en.unesco.org/sites/default/files/2858_15_ed_c op21_en.pdf on July 3, 2020.

van de Kamp M. E., Seves S. M. \& Temme E. H. M. (2018). Reducing GHG emissions while improving diet quality: exploring the potential of reduced meat, cheese and alcoholic and soft drinks consumption at specific moments during the day. BMC public health. 18(1): 264-264.

Vnetwork (2019). Statistical data on internet using in 2019 in Vietnam [Online]. Retrieved from https://vnetwork.vn/news/cac-so-lieu-thong-keinternet-viet-nam-2019 on July 15, 2020 (in Vietnamese).

Wang T. (2020). Plastic Waste Worldwide - Statistics \& Facts [Online]. Statista. Retrieved from https://www.statista.com/topics/5401/global-plasticwaste/ on June 18, 2020.

WMO (2019). Global Climate in 2015-2019: Climate change accelerates [Online]. Retrieved from https://public.wmo.int/en/media/press-release/globalclimate-2015-2019-climate-changeaccelerates\#: :text=The $\% 20 \mathrm{WMO} \% 20$ report $\% 20$ on \%20The,C\%20compared\%20to\%202011\%2D2015. on July $15,2020$. 